\title{
Evaluasi Penerimaan End-User terhadap Aplikasi University Customer Care Center (UC3) Universitas Jember dengan Menggunakan Pendekatan Unified Theory of Acceptance and Use of Technology (UTAUT)
}

\author{
Mitha Ariska*, Diah Ayu Retnani Wulandari**, Qurrota A'yuni Ar Ruhimat*** \\ *,***** Program Studi Sistem Informasi, Fakultas Ilmu Komputer, Universitas Jember \\ *mitha.ariska15@gmail.com,**diah.retnaniw@gmail.com,***qurrotaaar@unej.ac.id
}

\begin{abstract}
ABSTRAK
University Customer Care Center (UC3) is a complaint service system for active academic civitas of the University of Jember. Implementation of UC3 is expected to optimize complaints complaint related to performance evaluation at the University of Jember. One of the keys to the successful implementation of information technology, The purpose of the study is to know the factors that influence the acceptance of the academic civitas in using the UC3 application. This research will use the Unified Theory of Acceptance and Use of Technology (UTAUT) method by utilizing the Performance Expectancy (PE) variable, Effort Expectancy (EE), Social Influence (SI), and Facilitating Condition (FC) to see how it affects the intensity of application usage UC3 And the influence of moderator variables (Age and Experience) to the relationships of those variables. Based on the results of data analysis PLS-SEM known that the PE, EE, and SI variables have a positive and significant effect on the Behavioral Intention (BI) variables as well as the $\mathrm{FC}$ and $\mathrm{BI}$ variables significantly positive and significant to the Use Behavior (UB) variables. Age influences inter-variable relationships for ages 26-35 years, 36-45 years, and $>45$ years, while Experience influences the relationship between variables for usage intensity $\geq 3$ times. Based on the results of the five hypotheses received can be interpreted that the UC3 application was accepted by the academic and the acceptance is still not fully.
\end{abstract}

Keyword: Aplikasi UC3, Penerimaan Pengguna, UTAUT, PLS-SEM

\section{Pendahuluan}

University Customer Care Center (UC3) merupakan sistem pengaduan keluhan berbasis osticket yang dapat membuat aturan mengenai rute pengaduan [5]. UC3 diresmikan pada 15 November 2017 yang dikelola langsung oleh bagian HUMAS Universitas Jember [8]. Implementasi UC3 sebagai upaya dalam menumbuhkan kepedulian sivitas akademika terhadap peningkatan mutu pelayanan yang dilakukan oleh Universitas Jember. UC3 diharapkan dapat mengoptimalkan pelayanan pengaduan keluhan yang terkait evaluasi kinerja di Universitas Jember. UC3 memiliki dua fitur utama yaitu aduan internal dan aduan publik. Perbedaan dari dua fitur tersebut terdapat pada penggunanya, aduan internal disediakan bagi sivitas akademika sedangkan aduan publik disediakan bagi masyarakat sekitar Universitas Jember. Pengguna dapat melakukan pengaduan keluhan terkait delapan topik yang sudah ada antara lain akademik, kemahasiswaan, login SISTER, penelitian atau pengabdian, kepegawaian, keuangan, sarana dan prasarana, dan Wi-Fi dan email [7].

Sejak UC3 diresmikan hingga saat ini, dalam pengimplementasiannya tidak lepas dari banyak permasalahan. Berdasarkan hasil wawancara dengan sejumlah pengguna, masih banyak pengguna yang memilih mengakses aplikasi UC3 melalui perangkat mobile, namun saat diakses tampilannya kurang user friendly. Permasalahan lainnya yaitu beberapa pengguna menggunakan aplikasi UC3 hanya untuk membuat pengaduan keluhan saja tanpa melihat solusi yang diberikan, karena menurut mereka respon yang diberikan terlalu lama sehingga mereka langsung menghubungi kebagian terkait untuk menanyakan solusinya. Pada permasalahan tersebut pengguna UC3 cenderung menginginkan respon yang cepat. Berdasarkan permasalahan-permasalahan yang telah terjadi, maka diindikasikan bahwa penggunaan UC3 masih belum bisa dimaksimalkan berdasarkan kebutuhan pengguna sehingga perlu dilakukan perbaikan agar meningkatkan intensitas penggunaan aplikasi UC3.

Perbaikan tersebut dapat dilakukan dengan menganalisa faktor-faktor yang mempengaruhi penerimaan pengguna sehingga, dari faktor-faktor tersebut dapat diketahui apa saja yang perlu ditingkatkan. Hal ini dikarenakan menurut Wang \& Shih (2009) [10] salah satu kunci kesuksesan dari implementasi suatu teknologi informasi, bergantung pada kemauan pengguna untuk memakainya. Sedangkan agar suatu teknologi benar- 
benar dapat meningkatkan produktivitas organisasi, maka pengguna harus dapat menerima dan menggunakan teknologi tersebut [9]. Sejalan dengan pendapat tersebut, maka keberhasilan implementasi UC3 sangat ditentukan oleh respon pengguna terutama dari kalangan sivitas akademika. Apabila respon pengguna terhadap implementasi UC3 kurang baik maka implementasi UC3 tidak mencapai harapan.

Data dari UPT-TIK (2019) Universitas Jember menjelaskan bahwa jumlah sivitas akademika aktif yang menggunakan UC3 sebanyak 1187 dengan rincian pengguna yaitu mahasiswa sebanyak 767, dosen sebanyak 398, dan operator yang terdiri dari Satuan Pengawas Internal (SPI), LP2M, LP3M, UPT Perpustakaan, UPTBSPB, UPT-TIK, UPT Penerbitan, UPT Laboratorium Terpadu, UPT Agrotechnopark, dan UPT Kearsipan sebanyak 22, jika dibandingkan dengan total sivitas akademika aktif Universitas Jember hanya 3.6\% yang menggunakan UC3. Hal tersebut dikarenakan sampai saat ini masih banyak sivitas akademika yang melakukan pengaduan keluhan tidak melalui UC3 melainkan melalui email, telepon, maupun datang langsung ke bagian yang sesuai dengan bidang permasalahannya, seperti masalah akademik ke bagian BAAK, masalah sistem error ke bagian UPT-TIK, dan masalah umum ke bagian HUMAS [4]. Berdasarkan data dari UPT-TIK Universitas Jember tersebut, implementasi UC3 di Universitas Jember masih belum berjalan maksimal sehingga perlu adanya evaluasi penerimaan end-user terhadap aplikasi UC3 Universitas Jember.

Evaluasi penerimaan pengguna dalam bidang teknologi dan sistem informasi dapat diukur menggunakan banyak metode, salah satunya metode Unified Theory of Acceptance and Use of Technology (UTAUT) yang dikembangkan oleh Venkatesh, et al., (2003) [9]. Berdasarkan hasil penelitian Venkatesh, et al., (2003) [9] metode UTAUT dapat menjelaskan 70\% dari varian dalam niat untuk menggunakan teknologi yang lebih efektif dari model Theory of Reasoned Action (TRA), Technology Acceptance Model (TAM), Motivational Model (MM), Theory of Planned Behavior (TPB), Combined TAM and TPB (C-TAM-TPB), Model of PC Utilitzation (MPCU), Innovation Diffusion Theory (IDT), dan Social Cognitive Theory (SCT). Dibandingkan dengan metode lainnya, metode UTAUT lebih cocok digunakan dalam penelitian ini karena metode UTAUT memiliki variabel performance expectancy dan facilitating condition yang merupakan variabel paling berpengaruh dalam menjelaskan penerimaan teknologi informasi [3]. Metode UTAUT juga menunjukkan bahwa niat untuk berperilaku (behavioral intention) dan perilaku untuk menggunakan teknologi (use behavior) dipengaruhi oleh persepsi orang-orang terhadap harapan kinerja (performance expectancy), harapan usaha (effort expectancy), pengaruh sosial (social influence), dan kondisi yang membantu (facilitating condition) serta dimoderatori oleh usia (age), jenis kelamin (gender), pengalaman (experience), dan kesukarelaan pengguna (voluntariness of use). Hal tersebut sesuai dengan permasalahan yang ada pada aplikasi UC3 yaitu perilaku untuk menggunakan teknologi (use behavior) pada aplikasi UC3 dipengaruhi oleh beberapa faktor seperti tampilan yang kurang user friendly dan respon yang kurang cepat, faktor tersebut sesuai dengan indikator yang ada pada variabel performance expectancy dan facilitating condition.

Berdasarkan hal tersebut, pada penelitian ini dilakukan evaluasi penerimaan end-user terhadap aplikasi UC3 Universitas Jember menggunakan pendekatan UTAUT. Penelitian ini dapat digunakan untuk mengetahui faktor-faktor pendorong dan penghambat penerimaan aplikasi UC3. Selain itu, hasil penelitian ini dapat dijadikan sebagai dasar dalam penyusunan strategi untuk meningkatkan kualitas layanan UC3.

\section{Metodologi Penelitian}

Metodologi penelitian merupakan urutan langkah penelitian yang dilakukan selama proses penelitian berlangsung. Tahapan penelitian dapat dilihat pada Gambar 1 berikut :

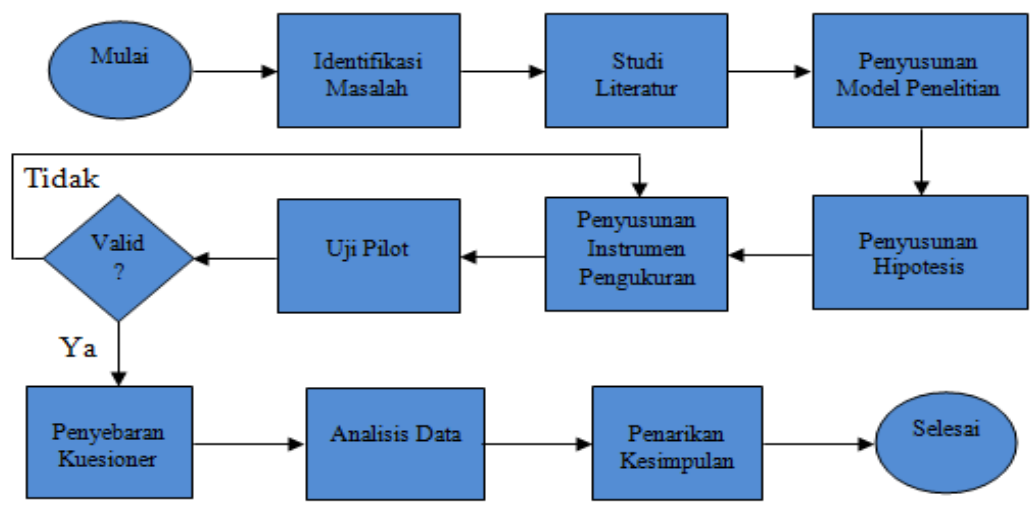

Gambar 1. Tahapan Penelitian

Pada penelitian ini pembuatan model konseptual mengacu pada model Unified Theory of Acceptance and Use of Technology (UTAUT) yang diadopsi dari penelitian Venkatesh, et al. pada tahun 2003 [9], kemudian disesuaikan dengan kondisi objek penelitian. Model konseptual pada penelitian ini dapat dilihat pada Gambar 2 berikut : 


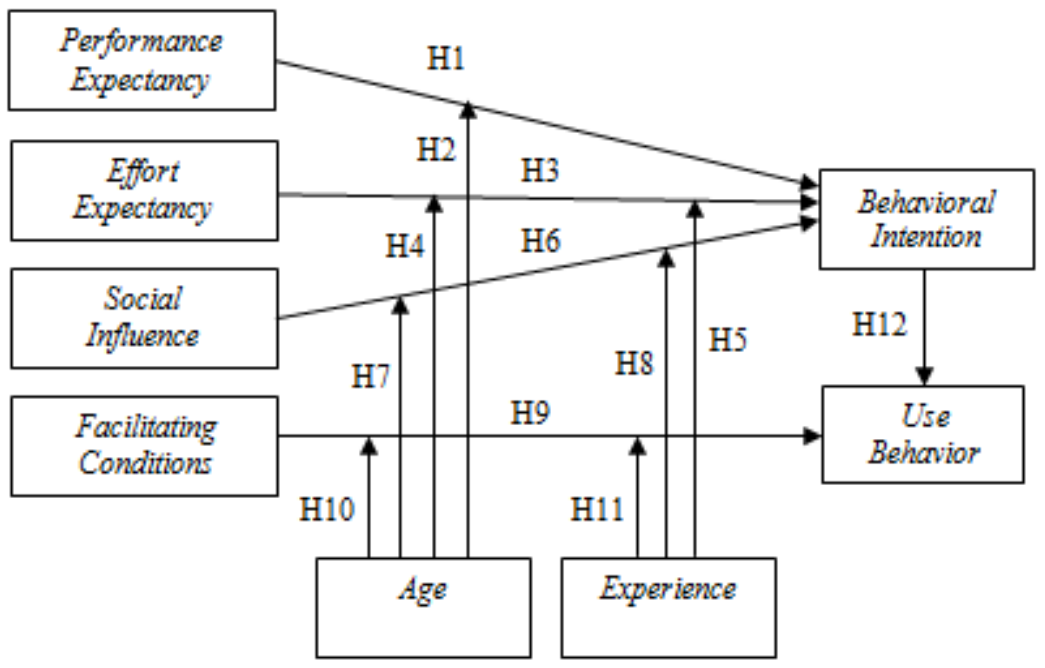

Gambar 2. Usulan Metode Penelitian

Berdasarkan model penelitian yang diusulkan seperti pada Gambar 2 tersebut, maka hipotesis yang dibentuk adalah sebagai berikut :

\section{Ekspetasi Kinerja (Performance Expectancy)}

H1 : Performance Expectancy (PE) berpengaruh positif dan signifikan terhadap Behavioral Intention (BI) pada penerimaan aplikasi UC3 di Universitas Jember.

H2 : ada pengaruh positif dan signifikan antara variabel Performance Expectancy (PE) terhadap variabel Behavioral Intention (BI) pada penerimaan aplikasi UC3 di Universitas Jember dan hal tersebut tidak dimoderasi oleh age.

\section{Ekspektasi Usaha (Effort Expectancy)}

H3 : Effort Expectancy (EE) berpengaruh positif dan signifikan terhadap Behavioral Intention (BI) pada penerimaan aplikasi UC3 di Universitas Jember.

H4 : ada pengaruh positif dan signifikan antara variabel Effort Expectancy (EE) terhadap variabel Behavioral Intention (BI) pada penerimaan aplikasi UC3 di Universitas Jember dan hal tersebut tidak dimoderasi oleh age. H5 : ada pengaruh positif dan signifikan antara variabel Effort Expectancy (EE) terhadap variabel Behavioral Intention (BI) pada penerimaan aplikasi UC3 di Universitas Jember dan hal tersebut tidak dimoderasi oleh experience.

\section{Pengaruh Sosial (Social Influence)}

H6 : Social Influence (SI) berpengaruh positif dan signifikan terhadap Behavioral Intention (BI) pada penerimaan aplikasi UC3 di Universitas Jember.

H7 : ada pengaruh positif dan signifikan antara variabel Social Influence (SI) terhadap variabel Behavioral Intention (BI) pada penerimaan aplikasi UC3 di Universitas Jember dan hal tersebut tidak dimoderasi oleh age. H8 : ada pengaruh positif dan signifikan antara variabel Social Influence (SI) terhadap variabel Behavioral Intention (BI) pada penerimaan aplikasi UC3 di Universitas Jember dan hal tersebut tidak dimoderasi oleh experience.

\section{Kondisi-Kondisi Fasilitas (Facilitating Condisions)}

H9 : Facilitating Condition (FC) berpengaruh positif dan signifikan terhadap Use Behavior (UB) pada penerimaan aplikasi UC3 di Universitas Jember.

H10 : ada pengaruh positif dan signifikan antara variabel Facilitating Condition (FC) terhadap variabel Use Behavior (UB) pada penerimaan aplikasi UC3 di Universitas Jember dan hal tersebut tidak dimoderasi oleh age.

H11 : ada pengaruh positif dan signifikan antara variabel Facilitating Condition (FC) terhadap variabel Use Behavior (UB) pada penerimaan aplikasi UC3 di Universitas Jember dan hal tersebut tidak dimoderasi oleh experience.

\section{Niat Penggunaan (Behavioral Intention)}

H12 : Behavioral Intention (BI) berpengaruh positif dan signifikan terhadap Use Behavior (UB) pada penerimaan aplikasi UC3 di Universitas Jember.

Teknik pengambilan sample pada penelitian ini menggunakan teknik probability sampling yaitu teknik pengambilan sampel yang memberikan peluang yang sama bagi setiap anggota populasi untuk dipilih menjadi anggota sampel [6]. Adapun populasi pada penelitian ini merupakan seluruh sivitas akademika 
Universitas Jember yang menggunakan aplikasi University Customer Care Center (UC3) meliputi mahasiswa, dosen, dan operator sebanyak 1187. Melihat besarnya populasi maka untuk menentukan sampel penelitian menggunakan teknik stratified random sampling [6] dengan alasan jumlah populasi penelitian yang besar dengan level atau strata dan terdapat kerangka sampel yang jelas meliputi jumlah pengguna disetiap level. Penentuan jumlah sampel pada penelitian ini akan dilakukan dengan perhitungan melalui rumus Slovin dengan penggunaan taraf kesalahan sebanyak 5\%, maka besar sampel pada penelitian ini yaitu 299 responden yang terdiri dari 193 mahasiswa, 100 dosen, dan enam operator yang ada di Universitas Jember.

Pada penelitian ini dilakukan uji pilot dengan mengumpulkan 10 orang misalnya dosen atau teman yang memiliki kualifikasi untuk membaca instrumen yang dalam hal ini adalah kuesioner yang akan digunakan untuk penelitian. Sementara untuk analisis data menggunakan metode Partial Least Square (PLS) dengan bantuan SmartPLS versi 3.2.8. Dalam penelitian ini akan dilakukan uji outer dan inner model, untuk uji outer model meliputi convergent validity, Avarage Variance Extracted (AVE), composite realibility, dan cronbach alpha, sedangkan untuk uji inner model meliputi R-Square, uji Goodness of Fit (GoF), uji hipotesis, dan uji hipotesis variabel moderator.

\section{Hasil dan Pembahasan}

\subsection{Responden Penelitian}

Penyebaran kuesioner dilakukan secara online dengan menyebarkan link kuesioner melalui media sosial, namun setelah beberapa minggu responden yang yang mengisi belum memenuhi target yang diharapkan. Kemudian peneliti meminta data rincian pengguna aplikasi University Customer Care Center (UC3) ke bagian UPT-TIK Universitas Jember, data tersebut digunakan untuk menghubungi maupun mendatangi pengguna UC3 secara langsung untuk menjadi responden kuesioner. Pada kuesioner online terdapat pertanyaan yang dijadikan penyaring responden dan untuk kuesioner yang disebarkan secara langsung diberikan pertanyaan untuk memastikan bahwa yang bersangkutan merupakan pengguna UC3.

Responden penelitian ini merupakan sivitas akademika aktif Universitas Jember sebanyak 299 yang terdiri dari 193 mahasiswa, 100 dosen, dan 6 operator. Total jumlah responden tersebut akan diklasifikasikan lagi berdasarkan umur dan pengalaman responden sebagai interpretasi dari variabel moderator yakni age dan experience. Jumlah total responden secara keseluruhan, berdasarkan tingkatan umur, dan berdasarkan pengalaman responden tertera pada Tabel 1 berikut :

Tabel 1. Responden Penelitian

\begin{tabular}{lc}
\hline \multicolumn{1}{c}{ Responden } & Jumlah \\
\hline Umur 15-25 tahun & 194 \\
Umur 26-35 tahun & 45 \\
Umur 36-45 tahun & 32 \\
Umur $>$ 45 tahun & 28 \\
Pengalaman 1-2 kali & 231 \\
Pengalaman $\geq 3$ kali & 68 \\
Keseluruhan & 299 \\
\hline
\end{tabular}

\subsection{Diagram Jalur Penelitian}

Diagram jalur model penelitian dikembangkan berdasarkan hipotesis yang diajukan dalam penelitian ini. Berdasarkan Gambar 3 terlihat bahwa diagram jalur model penelitian bersifat reflektif dengan menggunakan enam variabel dan 10 indikator yaitu :

1. Variabel Performance Expectancy (PE) dengan indikator Perceived Usefulness (PU), Outcome Expectations (OE), dan Relative Advantage (RA)

2. Variabel Effort Expectancy (EE) dengan indikator Perceived Ease of Use (PEOU)

3. Variabel Social Influence (SI) dengan indikator Subjective Norm (SN) dan Social Factors (SF)

4. Variabel Facilitating Conditions (FC) dengan indikator Perceived Behavioral Control (PBC) dan Facilitating Conditions (FC)

5. Variabel Behavioral Intention (BI) dengan indikator Behavioral Intention (BI)

6. Variabel Use Behavior (UB) dengan indikator Use Behavior (UB) 


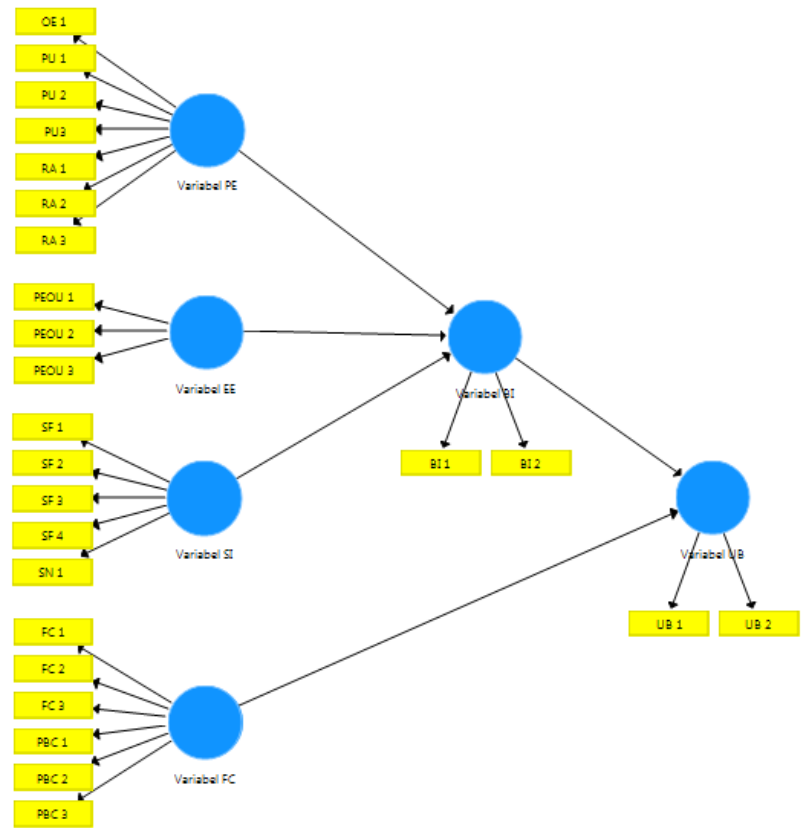

Gambar 3. Model Konseptual dengan Indikatornya

\subsection{Analisis Data}

\section{a. Outer Model}

Outer model sering juga disebut outer relation atau measurement model mendefinisikan hubungan antara setiap blok indikator dengan variabel latennya [2]. Berikut beberapa uji yang dapat dilakukan pada outer model adalah :

\section{Convergent Validity}

Sebelum melakukan analisis dilakukan terlebih dahulu dengan mengukur convergen validity. Convergent validity digunakan untuk memastikan bahwa indikator pada instrumen penelitian secara tepat mengukur variabel yang dimaksud atau validitas indikator terhadap variabelnya. Untuk melihat convergent validity dapat melihat nilai loading factor pada indikator terhadap variabelnya. Untuk melihat loading factor pada setiap indikator dapat dilihat pada Gambar 4 berikut :

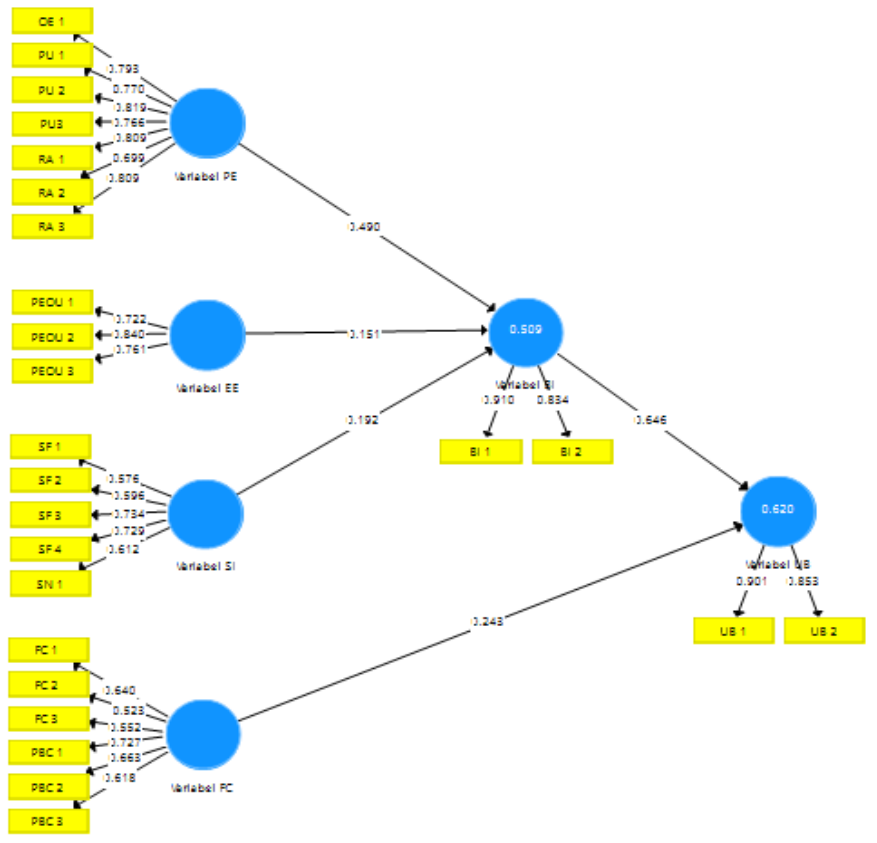

Gambar 4. Hasil Running Model PLS Tahap Awal

Nilai loading factor yang diharapkan pada penelitian ini yaitu melebihi 0.6 karena berdasarkan syarat yang ada nilai loading factor 0.6 dapat dikatakan cukup artinya apabila nilai loading factor melebihi 0.6 maka 
indikator tersebut mampu untuk menjelaskan variabel tersebut. Dalam Gambar 4 terdapat nilai loading factor yang dibawah 0.6 yaitu pada indikator Social Factors (SF 1 dan SF 2) serta Facilitating Conditions (FC 2 dan FC 3). Apabila terdapat nilai loading factor yang masih dibawah 0.6 maka indikator tersebut harus didrop atau dihapus. Setelah indikator tersebut dihapus maka program dijalankan ulang sehingga hasilnya seperti Gambar 5 berikut :

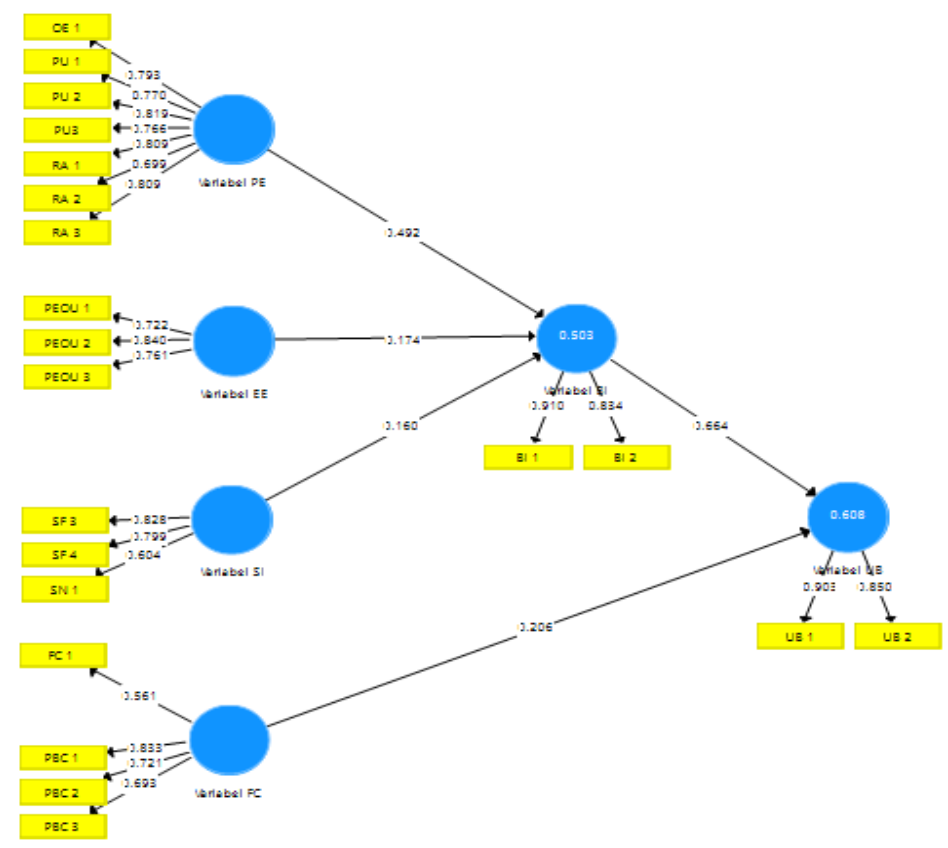

Gambar 5. Model Hasil Revisi Pertama

Pada Gambar 5 setelah indikator Social Factors (SF 1 dan SF 2) serta Facilitating Conditions (FC 2 dan FC 3) dihapus dan program dijalankan ulang ternyata masih ada indikator yang memiliki nilai loading factor dibawah 0.6 yaitu indikator Facilitating Conditions (FC 1) sehingga perlu didrop atau dihapus. Setelah indikator tersebut dihapus maka program dijalankan ulang sehingga hasilnya seperti Gambar 6 berikut :

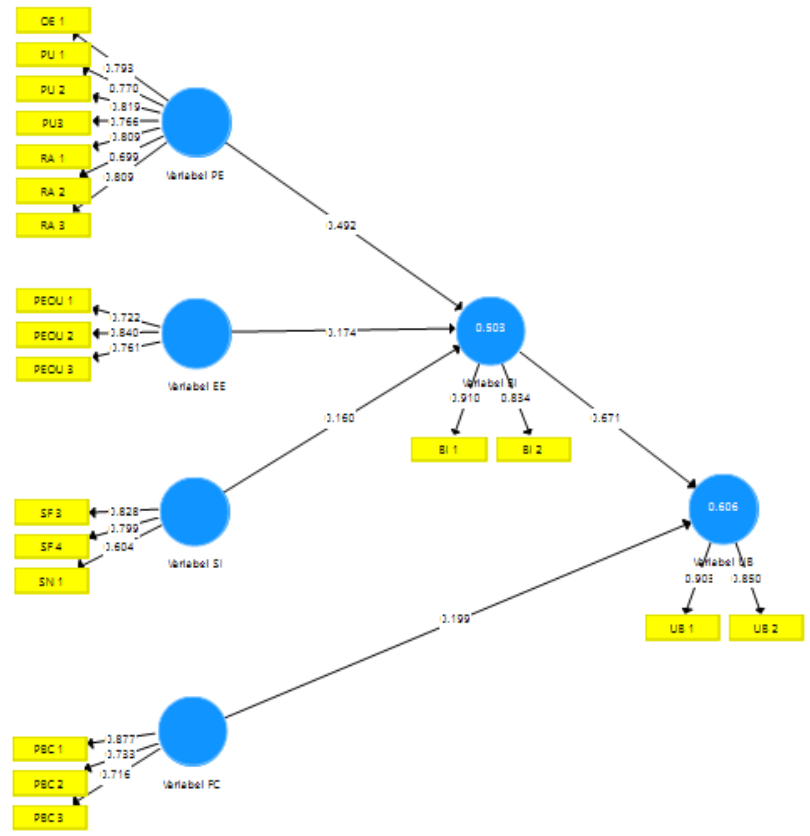

Gambar 6. Model Hasil Revisian Kedua

Pada Gambar 6 setelah indikator Facilitating Conditions (FC 1) dihapus dan program dijalankan ulang sudah tidak terdapat nilai loading factor yang berada dibawah 0.6 sehingga semua indikator sudah mampu menjelaskan variabelnya. Pada konstruk reflektif, menghilangkan satu indikator tidak akan mempengaruhi makna atas konstruk yang bersangkutan karena indikator yang merefleksikan konstruk yang bersangkutan memiliki sebaran loading factor yang covary yaitu dimana loading factor memiliki kesetaraan sebaran nilai satu sama lainnya [1]. 
2. Avarage Variance Extracted (AVE)

Nilai AVE digunakan untuk melihat besarnya nilai validitas dari sebuah variabel. Apabila nilainya melebihi 0.5 maka dapat dikatakan variabel tersebut memiliki validitas yang tinggi. Untuk melihat besarnya nilai AVE dapat dilihat pada Tabel 9 berikut :

Tabel 9. Nilai Avarage Variance Extracted (AVE)

\begin{tabular}{cc}
\hline Variabel & Nilai AVE \\
\hline Behavioral Intention (BI) & 0.762 \\
Effort Expectancy (EE) & 0.602 \\
Facilitating Condition (FC) & 0.606 \\
Performance Expectancy (PE) & 0.611 \\
Social Influence (SI) & 0.564 \\
Use Behavior (UB) & 0.769 \\
\hline
\end{tabular}

\section{Composite Reliability}

Composite reliability digunakan untuk melihat besarnya nilai reliabilitas dari sebuah variabel. Apabila nilainya melebihi 0.7 maka dapat dikatakan variabel tersebut memiliki reliabilitas yang tinggi. Untuk melihat besarnya nilai composite reliability dapat dilihat pada Tabel 10 berikut :

\begin{tabular}{cc} 
Tabel 10. Nilai Composite Reliability \\
\hline Variabel & Nilai Composite Reliability \\
\hline Behavioral Intention (BI) & 0.865 \\
Effort Expectancy (EE) & 0.819 \\
Facilitating Condition (FC) & 0.821 \\
Performance Expectancy (PE) & 0.916 \\
Social Influence (SI) & 0.792 \\
Use Behavior (UB) & 0.869 \\
\hline
\end{tabular}

\section{Cronbach's Alpha}

Nilai Cronbach's Alpha digunakan untuk melihat besarnya nilai reliabilitas dari sebuah variabel. Apabila nilainya melebihi 0.6 maka dapat dikatakan variabel tersebut memiliki reliabilitas yang tinggi. Untuk melihat besarnya nilai Cronbach's Alpha dapat dilihat pada Tabel 11 berikut. Tabel 11. Nilai Cronbach's Alpha

\begin{tabular}{cc}
\hline Variabel & Nilai Cronbach's Alpha \\
\hline Behavioral Intention (BI) & 0.693 \\
Effort Expectancy (EE) & 0.672 \\
Facilitating Condition (FC) & 0.675 \\
Performance Expectancy (PE) & 0.893 \\
Social Influence (SI) & 0.604 \\
Use Behavior (UB) & 0.702 \\
\hline
\end{tabular}

\section{b. Inner Model}

Inner model yang disebut juga dengan inner relation, structural model, dan subtantive theory menggambarkan hubungan antar variabel laten berdasarkan pada substantive theory [2]. Model regresi dapat dilakukan apabila proses outer model telah menunjukkan data instrumen adalah reliabel dan valid [1]. Berikut beberapa uji yang dapat dilakukan pada inner model adalah :

1. R-Square

Analisis $R$-Square digunakan untuk mengetahui besar pengaruh variabel independen terhadap variabel dependen tersebut, nilai dari $R$-Square dapat dilihat pada Tabel 12 berikut :

Tabel 12. Nilai $\mathrm{R}^{2}$

\begin{tabular}{lc}
\hline \multicolumn{1}{c}{ Variabel } & Nilai $\mathbf{R}^{\mathbf{2}}$ \\
\hline Behavioral Intention (BI) & 0.503 \\
Effort Expectancy (EE) & - \\
Facilitating Condition (FC) & - \\
Performance Expectancy (PE) & - \\
Social Influence (SI) & - \\
Use Behavior (UB) & 0.606 \\
\hline
\end{tabular}

Berdasarkan nilai $R$-Square pada Tabel 12 menunjukkan bahwa variabel Performance Expectancy (PE), Effort Expectancy (EE), dan Social Influence (SI) mampu menjelaskan variabel Behavioral Intention (BI) sebesar $50.3 \%$ dan sisanya sebesar $49.7 \%$ diterangkan oleh variabel lainnya diluar yang diteliti dalam penelitian ini. Sedangkan variabel Facilitating Condition (FC) dan Behavioral Intention (BI) mampu menjelaskan variabel Use Behavior (UB) sebesar 60.6\% dan sisanya sebesar 39.4\% diterangkan oleh variabel lainnya diluar yang diteliti dalam penelitian ini. 
2. Uji Goodness of Fit (GoF)

Uji ini digunakan untuk mengetahui seberapa baik model penelitian dalam menjelaskan data penelitian, untuk mengetahui nilai GoF pada PLS-SEM harus dicari secara manual seperti berikut.

$G o F=\sqrt{\overline{3.878} \times \overline{1.109}}$

GoF $=\sqrt{0.6463 \times 0.5545}$

$G o F=\sqrt{0.3583}=0.5985$

Dengan nilai GoF sebesar 0.5985 maka model penelitian dikategorikan sebagai GoF besar, sehingga dapat disimpulkan model penelitian ini secara substansial merepresentasikan hasil.

3. Uji Hipotesis

Uji hipotesis dilakukan untuk menentukan hipotesis mana saja yang diterima ataupun ditolak, untuk menentukan signifikan atau tidaknya hubungan suatu variabel adalah dengan membandingkan nilai $p$-values setelah proses bootsraping dengan taraf kesalahan atau nilai $\alpha$ penelitian. Penelitian ini menggunakan taraf kesalahan $5 \%$ atau $\alpha=0.05$ sehingga apabila nilai $p$-values $<0.05$ dan nilai $t$-statistics $>1.96$ hubungan suatu variabel dapat dikatakan signifikan dan sebaliknya, sedangkan untuk menentukan positif atau negatifnya hubungan suatu variabel adalah dengan melihat nilai original sample pada tabel path coefficient setelah proses bootstrapping, jika nilai yang dihasilkan adalah positif maka hubungan variabel tersebut dapat dikatakan positif dan begitupun sebaliknya. Tabel 13 merupakan hasil dari proses bootstraping untuk melihat nilai $p$-values, $t$ statistics, dan original sample.

Tabel 13. Nilai P-values, T-statistics, dan Original Sample Setelah Proses Bootstraping

\begin{tabular}{|l|c|c|c|c|}
\hline \multicolumn{1}{|c|}{ Variabel } & $\begin{array}{c}\text { Original } \\
\text { Sample }\end{array}$ & P-values & T-statistics & Keterangan \\
\hline $\begin{array}{l}\text { Variabel Performance Expectancy (PE) } \\
\text { terhadap variabel Behavioral Intention (BI) }\end{array}$ & 0.492 & 0.000 & 9.233 & $\begin{array}{l}\text { Positif dan } \\
\text { Sifgnifikan }\end{array}$ \\
\hline $\begin{array}{l}\text { Variabel Effort Expectancy (EE) terhadap } \\
\text { variabel Behavioral Intention (BI) }\end{array}$ & 0.174 & 0.007 & 2.718 & $\begin{array}{l}\text { Positif dan } \\
\text { Sifgnifikan }\end{array}$ \\
\hline $\begin{array}{l}\text { Variabel Social Influence (SI) terhadap } \\
\text { variabel Behavioral Intention (BI) }\end{array}$ & 0.160 & 0.002 & 3.089 & $\begin{array}{l}\text { Positif dan } \\
\text { Sifgnifikan }\end{array}$ \\
\hline $\begin{array}{l}\text { Variabel Facilitating Condition (FC) } \\
\text { terhadap variabel Use Behavior (UB) }\end{array}$ & 0.199 & 0.000 & 4.493 & $\begin{array}{l}\text { Positif dan } \\
\text { Sifgnifikan }\end{array}$ \\
\hline $\begin{array}{l}\text { Variabel Behavioral Intention (BI) terhadap } \\
\text { Use Behavior (UB) }\end{array}$ & 0.671 & 0.000 & 15.226 & $\begin{array}{l}\text { Positif dan } \\
\text { Sifgnifikan }\end{array}$ \\
\hline
\end{tabular}

a. Variabel PE atau harapan kinerja dalam penelitian ini berfokus pada kepercayaan seseorang bahwa aplikasi UC3 mampu mempermudah, meningkatkan efektivitas, mempercepat penangan penyelesaian, dan lebih baik daripada media pengaduan konvensional. Gambar 4 menunjukkan hubungan positif dan signifikan antara PE terhadap BI, yang artinya hipotesis $\mathrm{H} 1$ diterima. Apabila variabel PE atau performa aplikasi UC3 ditingkatkan maka niat sivitas akademika dalam menggunakan aplikasi UC3 akan meningkat secara signifikan.

b. Variabel EE atau harapan usaha dalam penelitian ini mengarah pada kemudahan dalam penggunaan aplikasi UC3, kemampuan aplikasi UC3 terkait pengaduan keluhan (membuat pengaduan keluhan, cek status aduan, statistik aduan), dan fleksibilitas penggunaan aplikasi UC3 yang dapat menyesuaikan dengan kebutuhan. Gambar 4 menunjukkan hubungan positif dan signifikan antara variabel EE terhadap BI, yang artinya hipotesis $\mathrm{H} 3$ diterima. Apabila variabel EE terkait kemudahan penggunaan aplikasi UC3 ditingkatkan maka hal tersebut akan mempengaruhi niat sivitas akademika secara signifikan dalam menggunakan aplikasi UC3.

c. Variabel SI atau pengaruh sosial dalam penelitian ini berfokus kepada Universitas Jember sebagai organisasi yang membantu dan mendukung penggunaan aplikasi UC3 serta pengaruh orang (rekanrekan/dosen/operator fakultas) yang ada di lingkungan Universitas Jember. Gambar 4 menunjukkan hubungan posif dan signifikan variabel SI terhadap BI, artinya hipotesis H6 diterima. Apabila variabel SI atau pengaruh sosial dalam penelitian ini ditingkatkan maka hal tersebut akan mempengaruhi niat sivitas akademika secara signifikan dalam menggunakan aplikasi UC3.

d. Variabel FC pada penelitian ini berfokus kepada infrastruktur dan sumberdaya yang mendukung implementasi sistem seperti panduan penggunaan aplikasi UC3, adanya sosialisasi penggunaan aplikasi UC3, dan tersedianya help desk yang dapat dihubungi ketika mengalami permasalahan terkait pengguaan aplikasi UC3. Gambar 4 menunjukkan hubungan positif dan signifikan hubungan variabel FC terhadap UB, artinya hipotesis $\mathrm{H} 9$ diterima. Apabila variabel FC atau kondisi yang memfasilitasi dalam penelitian ini semakin mendukung implementasi aplikasi UC3 maka akan semakin meningkat pula intensitas pengguaan aplikasi UC3, karena seperti contoh saat adanya sosialisasi dan panduan penggunaan aplikasi UC3 ditingkatkan maka akan meningkat secara signifikan pula niat sivitas akademika untuk menggunakan aplikasi UC3. 
e. Gambar 4 menunjukkan hubungan positif dan signifkan antara BI dan UB, artinya hipotesis H0 ditolak dan H12 dapat dikatakan diterima. Artinya adalah semakin tinggi niat sivitas akademika dalam menggunakan aplikasi UC3 maka akan semakin meningkat pula intensitas sivitas akademika dalam menggunakan aplikasi UC3, untuk meningkatkan niat sivitas akademika (variabel BI) maka harus ditingkatkan pula variabel PE, EE, dan SI yang merupakan variabel-variabel yang berpengaruh pada variabel BI.

Hasil hipotesis diatas terangkum dalam Tabel 14 berikut :

Tabel 14. Hasil Uji Hipotesis Tanpa Variabel Moderator

\begin{tabular}{|l|l|c|}
\hline & \multicolumn{1}{|c|}{ Hipotesis } & Kesimpulan \\
\hline H1 & $\begin{array}{l}\text { Performance Expectancy (PE) berpengaruh positif dan signifikan terhadap } \\
\text { Behavioral Intention (BI) pada penerimaan aplikasi UC3 di Universitas Jember. }\end{array}$ & Diterima \\
\hline H3 & $\begin{array}{l}\text { Effort Expectancy (EE) berpengaruh positif dan signifikan terhadap Behavioral } \\
\text { Intention (BI) pada penerimaan aplikasi UC3 di Universitas Jember. }\end{array}$ & Diterima \\
\hline H6 & $\begin{array}{l}\text { Social Influence (SI) berpengaruh positif dan signifikan terhadap Behavioral } \\
\text { Intention (BI) pada penerimaan aplikasi UC3 di Universitas Jember. }\end{array}$ & Diterima \\
\hline H9 & $\begin{array}{l}\text { Facilitating Condition (FC) berpengaruh positif dan signifikan terhadap Use } \\
\text { Behavior (UB) pada penerimaan aplikasi UC3 di Universitas Jember. }\end{array}$ & Diterima \\
\hline H12 & $\begin{array}{l}\text { Behavioral Intention (BI) berpengaruh positif dan signifikan terhadap Use } \\
\text { Behavior (UB) pada penerimaan aplikasi UC3 di Universitas Jember. }\end{array}$ & Diterima \\
\hline
\end{tabular}

4. Uji Hipotesis Variabel Moderator

a. Variabel Moderator Age

Variabel moderator age dalam penelitian ini diinterpretasikan kedalam tingkatan usia yakni 15-25 tahun, 26-35 tahun, 36-45 tahun, dan $>45$ tahun untuk melihat apakah tingkatan usia dapat mempengaruhi hubungan satu variabel terhadap variabel lainnya. Uji hipotesis dilakukan dengan melihat nilai $p$-values, $t$-statistics dan original sample.

Tabel 15. Nilai P-values, T-statistics, dan Original Sample Setelah Proses Bootstraping

\begin{tabular}{|c|c|c|c|c|}
\hline \multicolumn{5}{|c|}{ Variabel Moderator Age (Usia 15-25 tahun) } \\
\hline Variabel & $\begin{array}{l}\text { Original } \\
\text { Sample }\end{array}$ & P-values & T-statistics & Keterangan \\
\hline $\begin{array}{l}\text { Variabel Performance Expectancy }(\mathrm{PE}) \\
\text { terhadap variabel Behavioral Intention }(\mathrm{BI})\end{array}$ & 0.396 & 0.000 & 6.355 & $\begin{array}{l}\text { Positif dan } \\
\text { Sifgnifikan }\end{array}$ \\
\hline $\begin{array}{l}\text { Variabel Effort Expectancy (EE) terhadap } \\
\text { variabel Behavioral Intention (BI) }\end{array}$ & 0.239 & 0.001 & 3.222 & $\begin{array}{l}\text { Positif dan } \\
\text { Sifgnifikan }\end{array}$ \\
\hline $\begin{array}{l}\text { Variabel Social Influence (SI) terhadap } \\
\text { variabel Behavioral Intention (BI) }\end{array}$ & 0.178 & 0.006 & 2.758 & $\begin{array}{l}\text { Positif dan } \\
\text { Sifgnifikan }\end{array}$ \\
\hline $\begin{array}{l}\text { Variabel Facilitating Condition (FC) } \\
\text { terhadap variabel Use Behavior (UB) }\end{array}$ & 0.219 & 0.000 & 3.674 & $\begin{array}{l}\text { Positif dan } \\
\text { Sifgnifikan }\end{array}$ \\
\hline \multicolumn{5}{|c|}{ Variabel Moderator Age (Usia 26-35 tahun) } \\
\hline Variabel & $\begin{array}{l}\text { Original } \\
\text { Sample }\end{array}$ & P-values & T-statistics & Keterangan \\
\hline $\begin{array}{l}\text { Variabel Performance Expectancy (PE) } \\
\text { terhadap variabel Behavioral Intention (BI) }\end{array}$ & 0.717 & 0.000 & 5.152 & $\begin{array}{l}\text { Positif dan } \\
\text { Sifgnifikan }\end{array}$ \\
\hline $\begin{array}{l}\text { Variabel Effort Expectancy (EE) terhadap } \\
\text { variabel Behavioral Intention (BI) }\end{array}$ & -0.076 & 0.509 & 0.611 & $\begin{array}{c}\text { Negatif dan } \\
\text { Tidak } \\
\text { Signifikan }\end{array}$ \\
\hline $\begin{array}{l}\text { Variabel Social Influence (SI) terhadap } \\
\text { variabel Behavioral Intention (BI) }\end{array}$ & 0.235 & 0.114 & 1.585 & $\begin{array}{l}\text { Positif dan } \\
\text { Tidak } \\
\text { Signifikan }\end{array}$ \\
\hline $\begin{array}{l}\text { Variabel Facilitating Condition (FC) } \\
\text { terhadap variabel Use Behavior (UB) }\end{array}$ & 0.332 & 0.000 & 3.508 & $\begin{array}{l}\text { Positif dan } \\
\text { Sifgnifikan }\end{array}$ \\
\hline \multicolumn{5}{|c|}{ Variabel Moderator Age (Usia 36-45 tahun) } \\
\hline Variabel & $\begin{array}{l}\text { Original } \\
\text { Sample }\end{array}$ & P-values & T-statistics & Keterangan \\
\hline $\begin{array}{l}\text { Variabel Performance Expectancy }(\mathrm{PE}) \\
\text { terhadap variabel Behavioral Intention }(\mathrm{BI})\end{array}$ & 0.633 & 0.000 & 3.563 & $\begin{array}{l}\text { Positif dan } \\
\text { Sifgnifikan }\end{array}$ \\
\hline $\begin{array}{l}\text { Variabel Effort Expectancy (EE) terhadap } \\
\text { variabel Behavioral Intention (BI) }\end{array}$ & 0.015 & 0.937 & 0.079 & $\begin{array}{l}\text { Positif dan } \\
\text { Tidak } \\
\text { Signifikan }\end{array}$ \\
\hline
\end{tabular}




\begin{tabular}{|c|c|c|c|c|}
\hline Variabel & $\begin{array}{l}\text { Original } \\
\text { Sample }\end{array}$ & P-values & T-statistics & Keterangan \\
\hline $\begin{array}{l}\text { Variabel Social Influence (SI) terhadap } \\
\text { variabel Behavioral Intention (BI) }\end{array}$ & 0.279 & 0.027 & 2.218 & $\begin{array}{l}\text { Positif dan } \\
\text { Sifgnifikan }\end{array}$ \\
\hline $\begin{array}{l}\text { Variabel Facilitating Condition (FC) } \\
\text { terhadap variabel Use Behavior (UB) }\end{array}$ & 0.313 & 0.019 & 2.349 & $\begin{array}{l}\text { Positif dan } \\
\text { Sifgnifikan }\end{array}$ \\
\hline \multicolumn{5}{|c|}{ Variabel Moderator Age (Usia $>45$ tahun) } \\
\hline Variabel & $\begin{array}{l}\text { Original } \\
\text { Sample }\end{array}$ & P-values & T-statistics & Keterangan \\
\hline $\begin{array}{l}\text { Variabel Performance Expectancy }(\mathrm{PE}) \\
\text { terhadap variabel Behavioral Intention (BI) }\end{array}$ & 0.341 & 0.036 & 2.100 & $\begin{array}{l}\text { Positif dan } \\
\text { Signifikan }\end{array}$ \\
\hline $\begin{array}{l}\text { Variabel Effort Expectancy (EE) terhadap } \\
\text { variabel Behavioral Intention (BI) }\end{array}$ & 0.304 & 0.105 & 1.623 & $\begin{array}{l}\text { Positif dan } \\
\text { Tidak } \\
\text { Signifikan }\end{array}$ \\
\hline $\begin{array}{l}\text { Variabel Social Influence (SI) terhadap } \\
\text { variabel Behavioral Intention (BI) }\end{array}$ & 0.317 & 0.102 & 1.640 & $\begin{array}{l}\text { Positif dan } \\
\text { Tidak } \\
\text { Signifikan }\end{array}$ \\
\hline $\begin{array}{l}\text { Variabel Facilitating Condition (FC) } \\
\text { terhadap variabel Use Behavior (UB) }\end{array}$ & 0.333 & 0.026 & 2.232 & $\begin{array}{l}\text { Positif dan } \\
\text { Sifgnifikan }\end{array}$ \\
\hline
\end{tabular}

Berdasarkan nilai p-values, $t$-statistics, dan original sample yang dihasilkan oleh tiap variabel melalui olah data oleh SmartPLS maka kesimpulan uji hipotesis yang didapat terangkum dalam Tabel 16 berikut :

Tabel 16. Uji Hipotesis Variabel Moderator Age

\begin{tabular}{|l|l|c|}
\hline & \multicolumn{1}{|c|}{ Hipotesis } & Kesimpulan \\
\hline H2 & $\begin{array}{l}\text { ada pengaruh positif dan signifikan antara variabel } \\
\text { Performance Expectancy (PE) terhadap variabel Behavioral } \\
\text { Intention (BI) pada penerimaan aplikasi UC3 di Universitas } \\
\text { Jember dan hal tersebut tidak dimoderasi oleh age. }\end{array}$ & Diterima \\
\hline H4 & $\begin{array}{l}\text { ada pengaruh positif dan signifikan antara variabel Effort } \\
\text { Expectancy (EE) terhadap variabel Behavioral Intention (BI) } \\
\text { pada penerimaan aplikasi UC3 di Universitas Jember dan hal } \\
\text { tersebut tidak dimoderasi oleh age. }\end{array}$ & Ditolak \\
\hline H7 & $\begin{array}{l}\text { ada pengaruh positif dan signifikan antara variabel Social } \\
\text { Influence (SI) terhadap variabel Behavioral Intention (BI) } \\
\text { pada penerimaan aplikasi UC3 di Universitas Jember dan hal } \\
\text { tersebut tidak dimoderasi oleh age. }\end{array}$ & 2 Hipotesis Diterima dan \\
2 Hipotesis Ditolak \\
\hline H10 & $\begin{array}{l}\text { ada pengaruh positif dan signifikan antara variabel } \\
\text { Facilitating Condition (FC) terhadap variabel Use Behavior } \\
\text { (UB) pada penerimaan aplikasi UC3 di Universitas Jember } \\
\text { dan hal tersebut tidak dimoderasi oleh age. }\end{array}$ & Diterima \\
\hline
\end{tabular}

b. Variabel Moderator Experience

Variabel moderator experience dalam penelitian ini diintepretasikan kedalam tingkatan intensitas penggunaan yakni 1-2 kali dan $\geq 3$ kali untuk melihat apakah tingkatan intensitas penggunaan dapat mempengaruhi hubungan satu variabel terhadap variabel lainnya. Uji hipotesis dilakukan dengan melihat nilai $p$-values, $t$-statistics dan original sample.

Tabel 17. Nilai P-values, T-statistics, dan Original Sample Setelah Proses Bootstraping

\begin{tabular}{|l|c|c|c|c|}
\hline \multicolumn{7}{|c|}{ Variabel Moderator Experience (1-2 kali) } \\
\hline \multicolumn{1}{|c|}{ Variabel } & $\begin{array}{c}\text { Original } \\
\text { Sample }\end{array}$ & P-values & T-statistics & Keterangan \\
\hline $\begin{array}{l}\text { Variabel Effort Expectancy (EE) terhadap } \\
\text { variabel Behavioral Intention (BI) }\end{array}$ & 0.199 & 0.006 & 2.742 & $\begin{array}{c}\text { Positif dan } \\
\text { Signifikan }\end{array}$ \\
\hline $\begin{array}{l}\text { Variabel Social Influence (SI) terhadap } \\
\text { variabel Behavioral Intention (BI) }\end{array}$ & 0.174 & 0.006 & 2.753 & $\begin{array}{c}\text { Positif dan } \\
\text { Signifikan }\end{array}$ \\
\hline $\begin{array}{l}\text { Variabel Facilitating Condition (FC) } \\
\text { terhadap variabel Use Behavior (UB) }\end{array}$ & 0.262 & 0.000 & 4.550 & $\begin{array}{c}\text { Positif dan } \\
\text { Signifikan }\end{array}$ \\
\hline
\end{tabular}




\begin{tabular}{|l|c|c|c|c|}
\hline \multicolumn{4}{|c|}{ Variabel Moderator Experience ( $\geq \mathbf{3}$ kali) } \\
\hline \multicolumn{1}{|c|}{ Variabel } & $\begin{array}{c}\text { Original } \\
\text { Sample }\end{array}$ & P-values & T-statistics & Keterangan \\
\hline $\begin{array}{l}\text { Variabel Effort Expectancy (EE) terhadap } \\
\text { variabel Behavioral Intention (BI) }\end{array}$ & -0.033 & 0.806 & 0.246 & $\begin{array}{c}\text { Negatif dan } \\
\text { Tidak } \\
\text { Signifikan }\end{array}$ \\
\hline $\begin{array}{l}\text { Variabel Social Influence (SI) terhadap } \\
\text { variabel Behavioral Intention (BI) }\end{array}$ & 0.147 & 0.133 & 1.505 & $\begin{array}{c}\text { Positif dan } \\
\text { Tidak } \\
\text { Signifikan }\end{array}$ \\
\hline $\begin{array}{l}\text { Variabel Facilitating Condition (FC) } \\
\text { terhadap variabel Use Behavior (UB) }\end{array}$ & 0.141 & 0.072 & 1.803 & $\begin{array}{c}\text { Positif dan } \\
\text { Tidak } \\
\text { Signifikan }\end{array}$ \\
\hline
\end{tabular}

Berdasarkan nilai $p$-values, $t$-statistics, dan original sample pada Tabel 17 maka kesimpulan uji hipotesis untuk variabel moderator experience adalah sebagai berikut :

Tabel 18. Uji Hipotesis Variabel Moderator Experience

\begin{tabular}{|l|l|c|}
\hline & \multicolumn{1}{|c|}{ Hipotesis } & \multicolumn{1}{|c|}{ Kesimpulan } \\
\hline H5 & $\begin{array}{l}\text { ada pengaruh positif dan signifikan antara variabel Effort } \\
\text { Expectancy (EE) terhadap variabel Behavioral Intention (BI) } \\
\text { pada penerimaan aplikasi UC3 di Universitas Jember dan hal } \\
\text { tersebut tidak dimoderasi oleh experience. }\end{array}$ & $\begin{array}{c}\text { 1 Hipotesis Diterima dan 1 } \\
\text { Hipotesis Ditolak }\end{array}$ \\
\hline H8 & $\begin{array}{l}\text { ada pengaruh positif dan signifikan antara variabel Social } \\
\text { Influence (SI) terhadap variabel Behavioral Intention (BI) } \\
\text { pada penerimaan aplikasi UC3 di Universitas Jember dan hal } \\
\text { tersebut tidak dimoderasi oleh experience. }\end{array}$ & $\begin{array}{c}\text { 1 Hipotesis Diterima dan 1 } \\
\text { Hipotesis Ditolak }\end{array}$ \\
\hline H11 & $\begin{array}{l}\text { ada pengaruh positif dan signifikan antara variabel } \\
\text { Facilitating Condition (FC) terhadap variabel Use Behavior } \\
\text { (UB) pada penerimaan aplikasi UC3 di Universitas Jember } \\
\text { dan hal tersebut tidak dimoderasi oleh experience. }\end{array}$ & $\begin{array}{c}\text { 1 Hipotesis Diterima dan 1 } \\
\text { Hipotesis Ditolak }\end{array}$ \\
\hline
\end{tabular}

Berdasarkan uji hipotesis tanpa variabel moderator dan dengan menggunakan variabel moderator, maka didapatkan hasil perbandingan yang terangkum dalam Tabel 19 berikut :

Tabel 19. Perbandingan Hubungan Antar Variabel Tanpa Moderator dan Dengan Moderator

\begin{tabular}{|c|c|c|c|}
\hline Variabel & $\begin{array}{c}\text { Hubungan Variabel } \\
\text { (Data Keseluruhan } \\
\text { Tanpa Variabel } \\
\text { Moderator) } \\
\end{array}$ & $\begin{array}{c}\text { Hubungan Variabel } \\
\text { dengan Adanya } \\
\text { Variabel Moderator } \\
\text { Age } \\
\end{array}$ & $\begin{array}{c}\text { Hubungan Variabel } \\
\text { dengan Adanya Variabel } \\
\text { Moderator Experience }\end{array}$ \\
\hline $\begin{array}{l}\text { Performance } \\
\text { Expectancy }(\mathrm{PE}) \\
\text { terhadap Behavioral } \\
\text { Intention }(\mathrm{BI}) \\
\end{array}$ & Positif dan Signifikan & Positif dan Signifikan & - \\
\hline $\begin{array}{l}\text { Effort Expectancy } \\
\text { (EE) terhadap } \\
\text { Behavioral Intention } \\
\text { (BI) }\end{array}$ & Positif dan Signifikan & $\begin{array}{l}\text { Positif dan Tidak } \\
\text { Signifikan (untuk usia } \\
\text { 15-25 tahun) dan } \\
\text { Negatif dan Tidak } \\
\text { Signifikan (untuk usia } \\
\text { 26-35 tahun) dan } \\
\text { Positif dan Tidak } \\
\text { Signifikan (untuk usia } \\
\text { 36-45 tahun dan }>45 \\
\text { tahun) }\end{array}$ & $\begin{array}{l}\text { Positif dan Signifikan } \\
\text { (untuk intensitas } \\
\text { penggunaan } 1-2 \text { kali), } \\
\text { Negatif dan Tidak } \\
\text { Signifikan (untuk intensitas } \\
\text { penggunaan } \geq 3 \text { kali) }\end{array}$ \\
\hline $\begin{array}{l}\text { Social Influence (SI) } \\
\text { terhadap Behavioral } \\
\text { Intention (BI) }\end{array}$ & Positif dan Signifikan & $\begin{array}{l}\text { Positif dan Signifikan } \\
\text { (untuk usia 15-25 } \\
\text { tahun dan 36-45 } \\
\text { tahun) dan Positif dan } \\
\text { Tidak Signifikan } \\
\text { (untuk usia 26-35 } \\
\text { tahun dan }>45 \text { tahun) }\end{array}$ & $\begin{array}{l}\text { Positif dan Signifikan } \\
\text { (untuk intensitas } \\
\text { penggunaan } 1-2 \text { kali) dan } \\
\text { Positif dan Tidak Signifikan } \\
\text { (untuk intensitas } \\
\text { penggunaan } \geq 3 \text { kali) }\end{array}$ \\
\hline
\end{tabular}




\begin{tabular}{|l|c|c|c|}
\hline \multicolumn{1}{|c|}{ Variabel } & $\begin{array}{c}\text { Hubungan Variabel } \\
\text { (Data Keseluruhan } \\
\text { Tanpa Variabel } \\
\text { Moderator) }\end{array}$ & $\begin{array}{c}\text { Hubungan Variabel } \\
\text { dengan Adanya } \\
\text { Variabel Moderator } \\
\text { Age }\end{array}$ & $\begin{array}{c}\text { Hubungan Variabel } \\
\text { dengan Adanya Variabel } \\
\text { Moderator Experience }\end{array}$ \\
\hline $\begin{array}{l}\text { Facilitating } \\
\text { Condition } \\
\text { (FC) terhadap Use } \\
\text { Behavior (UB) }\end{array}$ & Positif dan Signifikan & Positif dan Signifikan & $\begin{array}{l}\text { Positif dan Signifikan } \\
\text { (untuk intensitas } \\
\text { penggunaan 1-2 kali) dan } \\
\text { Positif dan Tidak Signifikan } \\
\text { (untuk intensitas } \\
\text { penggunaan } \geq 3 \text { kali) }\end{array}$ \\
\hline $\begin{array}{l}\text { Behavioral Intention } \\
\text { (BI) terhadap Use } \\
\text { Behavior (UB) }\end{array}$ & Positif dan Signifikan & - & \\
\hline
\end{tabular}

5. Penerimaan Aplikasi University Customer Care Center (UC3)

Berdasarkan hasil kelima hipotesis yang diterima dapat diinterpretasikan bahwa aplikasi UC3 diterima oleh sivitas akademika dan bermanfaat dalam membuat pengaduan keluhan terkait permasalahan yang ada di Universitas Jember. Pada penelitian ini skor penilaian kuesioner menggunakan skala likert satu samapi empat, sehingga nilai rata-rata dari tanggapan responden yang maksimal yaitu empat. Namun berdasarkan nilai ratarata dari tanggapan responden terhadap penyebaran kuesioner masih menghasilkan nilai rata-rata yang belum maksimal yaitu nilai 2.3 sampai dengan nilai 3.4, artinya penerimaan tersebut masih belum sepenuhnya. Dari kuesioner yang sudah disebarkan ada beberapa pertanyaan yang memiliki nilai rata-rata tanggapan responden yang kecil yaitu kurang dari tiga, seperti pertanyaan pada variabel Performance Expectancy (PE) mengenai solusi dan respon yang diberikan kurang jelas dan cepat, variabel Effort Expectancy (EE) mengenai aplikasi UC3 yang masih belum bisa memenuhi apa yang dibutuhkan dalam hal pengaduan keluhan, variabel Social Influence (SI) mengenai dukungan dari Pimpinan Universitas Jember/Pimpinan Fakultas dan pengaruh dari orang lain serta pada variabel Facilitating Condition (FC) mengenai panduan penggunaan, sosialisasi, instruksi penggunaan, maupun help desk yang dapat dihubungi saat mengalami kesulitan dalam menggunakan aplikasi UC3.

Pada variabel moderator age untuk usia 15-25 tahun tidak memilki pengaruh terhadap hubungan dari semua variabel pada usia tersebut kebanyakan responden berstatus mahasiswa yang mudah beradaptasi dalam menggunakan teknologi. Untuk usia 26-35 tahun, 36-45 tahun, dan $>45$ tahun tidak memilki pengaruh pada hubungan variabel FC terhadap UB dan variabel PE terhadap BI karena mereka beranggapan memiliki sumberdaya dan pengetahuan untuk penggunaanUC3 serta mereka beranggapan dengan adanya UC3 dapat membantu mereka dalam melakukan pengaduan keluhan. Pada usia 36-45 tahun tidak memiliki pengaruh pada variabel SI terhadap BI karena UC3 merupakan produk dari Universitas Jember yang merupakan tempat kerja mereka sehingga mereka beranggapan harus menggunakan aplikasi tersebut.

Sementara untuk usia 26-35 tahun, 36-45 tahun, dan $>45$ memiliki pengaruh pada variabel EE terhadap BI karena menurut mereka UC3 masih belum bisa memenuhi apa yang mereka butuhkan dalam hal pengaduan keluhan. Pada usia 26-35 tahun dan $>45$ tahun memilki pengaruh pada variabel SI terhadap BI karena pada usia tersebut sudah memilki pemikiran yang matang sehingga tidak dapat dipengaruhi untuk menggunakan aplikasi UC3. Pada variabel moderator experience untuk intensitas penggunaan 1-2 kali tidak memiliki pengaruh terhadap hubungan dari semua variabel sedangkan untuk intensitas penggunaan $\geq 3$ kali memiliki pengaruh terhadap hubungan dari semua variabel karena mereka sering menggunakan aplikasi UC3 untuk melakukan pengaduan keluhan sehingga mereka mengetahui penggunaan dari aplikasi UC3.

\section{Kesimpulan}

Berdasarkan uraian pada bagian pembahasan, maka kesimpulan yang didapat adalah :

1. Dari hasil uji hipotesis yang dilakukan menggunakan PLS-SEM dengan bantuan aplikasi SmartPLS versi 3.2.8 diketahui bahwa kelima hipotesis diterima. Hal tersebut berarti variabel Performance Expectancy (PE), Effort Expectancy (EE), Social Influence (SI), Facilitating Condition (FC), dan Behavioral Intention (BI) mempengaruhi variabel Use Behavior (UB) dalam penerimaan aplikasi University Customer Care Center (UC3) Universitas Jember pada end-user.

2. Pada variabel moderator age untuk usia 15-25 tahun tidak memiliki pengaruh terhadap hubungan dari semua variabel sedangkan pada usia 26-35 tahun dan usia $>45$ tahun tidak memilki pengaruh pada variabel Facilitating Condition (FC) terhadap variabel Use Behavior (UB) dan variabel Performance Expectancy (PE) terhadap variabel Behavioral Intention (BI) namun memiliki pengaruh terhadap hubungan variabel Social Influence (SI) dan Effort Expectancy (EE) terhadap variabel Behavioral Intention (BI). Sementara untuk usia 36-45 tahun tidak memilki pengaruh pada variabel Facilitating Condition (FC) terhadap variabel 
Use Behavior (UB) serta variabel Performance Expectancy (PE) dan Social Influence (SI)terhadap variabel Behavioral Intention (BI) namun memiliki pengaruh pada variabel Effort Expectancy (EE) terhadap variabel Behavioral Intention (BI). Pada intesitas penggunaan 1-2 kali tidak memiliki pengaruh sementara untuk intesitas penggunaan $\geq 3$ kali memiliki pengaruh terhadap hubungan dari semua variabel.

3. Berdasarkan hasil kelima hipotesis yang diterima dapat diinterpretasikan bahwa aplikasi UC3 diterima oleh sivitas akademika dan bermanfaat dalam membuat pengaduan keluhan terkait permasalahan yang ada di Universitas Jember. Namun berdasarkan nilai rata-rata dari tanggapan responden terhadap penyebaran kuesioner masih menghasilkan nilai rata-rata yang belum maksimal yaitu nilai 2.3 sampai dengan nilai 3.4, artinya penerimaan tersebut masih belum sepenuhnya.

\section{Daftar Pustaka}

[1] Budhiasa, S. (2016). Analisis Statistik Multivariate dengan Aplikasi SEM PLS SMARTPLS 3.2.6. Denpasar: Udayana University Press.

[2] Ghozali, I. (2014). Structural Equation Modeling, Metode Alternatif dengan Partial Least Square. Semarang: Badan Penerbit Universitas Diponegoro.

[3] Hamrul, H., Soedijono, B., \& Amborowati, A. (2013). Analisis Perbandingan Metode TAM dan UTAUT Dalam Mengukur Kesuksesan Penerapan Sistem Informasi Akademik (Studi Kasus Penerapan Sistem Informasi STMIK Dipanegara Makasar). Seminar Nasional Informatika 2013 (semnasIF 2013) , A-140A146.

[4] Ilham, I. F. (2019, Januari 10). Wawancara Mengenai University Customer Care Canter (UC3). (Y. Triani, Pewawancara)

[5] Nuritha, I. (2018, Oktober 4). Wawancara Mengenai University Customer Care Canter (UC3). (M. Ariska, Pewawancara)

[6] Sugiyono. (2015). Metode Penelitian Pendidikan (Pendekatan Kuantitatif, Kualitatif, dan R\&D). Bandung: Alfabeta.

[7] UC3-UNEJ. (2018). University Customer Care Center Pusat Layanan Terpadu Publik dan Warga Universitas Jember. Dipetik 11 26, 2018, dari UC3-Universitas Jember: https://uc3.unej.ac.id/home/

[8] Universitas Jember. (2017, Desember 22). Universitas Jember Tingkatkan Akuntabilitas Melalui UC3. Dipetik November 14, 2018, dari Berita Universitas Jember: https:/unej.ac.id/universitas-jembertingkatkan-akuntabilitas-melalui-uc3/

[9] Venkatesh, V., Morris, M. G., Davis, G. B., \& Davis, F. D. (2003). User Acceptance Of Information Technology: Toward A Unified View. MIS Quarterly Vol. 27 No. 3, 425-478.

[10] Wang, Y.-S., \& Shih, Y.-W. (2009). Why do people use information kiosks? A validation of the Unified Theory of. Government Information Quarterly, 158-165. 